\title{
Resources of civil culture in the Republic of Tatarstan in the last quarter of the 20th century
}

\author{
Dilovar Kalimullin ${ }^{1, *}$, and Gul'zirak Kalimullina ${ }^{1}$ \\ ${ }^{1}$ Kazan State Institute of Culture, 420059, 3 Orenburgskiy trakt, Kazan, Russia
}

\begin{abstract}
Process of formation of the civil sector has significantly accelerated in recent years. It became the instrument of social policy, school of political culture and a form of civil participation. In the activity, they are guided by modern concepts of civil society, which has been developed in a subsoil of the liberal culture. Directly or indirectly, their ideological platforms include values of the free personality, the principles of the constitutional state and private property, security of all subjects from any decisions, independence of mass media, compliance of the domestic legislation to the universally recognized norms and the principles of international law. The paper is also devoted to studying the questions of formation of public associations in the Republic of Tatarstan.
\end{abstract}

\section{Introduction}

The research issue of public associations as a civil society structural element and as a mean of civic culture development is highly topical today. It is well known, that social and cultural updating priorities of Russian society are values of democracy, humanism, personal rights and freedom. Based on a social pedagogical approach, this refers to the creation of an environment for the human personality full development as a social relationship actor, a statement of civic-mindedness as a mean of human and social development in the popular consciousness. Public societies have an important resource for citizenship foundation. The Russian "third sector" of that period consisted of thousands of organizations, initiating and implementing the publicly significant and useful projects; tens of thousands of volunteers gratuitously working for other people; millions of citizens - public association members. It is a field of professional self-realization on demand of innovative socio-cultural technology, providing employment of a significant number of citizens. Public associations today is a real power of civil society, this was evidenced through their social initiatives' dimension, crime and drug abuse prevention efforts and promotion of charity as a mean of personal self-realization and social value. The public associations' activity provides real conditions for citizens' influence on the legislative process, on the process of political, economic and social reforms. The competence of public associations to include a person in the system of public relations in order to address socially significant issues, turn them into a school of political culture, as a form of civic participation, the vehicle providing an active position and the individual moral responsibility.

\footnotetext{
* Corresponding author: yearsgoby@ yandex.ru
} 
However, the public associations' capacity to provide the civic culture is not fully implemented. This is due to several factors: the "third sector" commercialization and emasculation of the socio-cultural nature of this phenomenon; the traditional view on public associations as the leisure activity, which functions are limited to organization of the conditions for socialization and personal fulfillment; the absence of socio-cultural technologies and forms of public associations' interaction with other actors addressing social problems' deficiency, which violates the third sector civil nature implementation; the crudity of theoretical issues related to contemporary forms of civic participation, establishing partnership with government, business and various actors of social and cultural life. The research interest is focused on sociological, legal, economic and organizational aspects of interaction between the "third sector" and business, non-profit organizations and power structures. At the same time, the public associations' competencies in the formation of the individual civic culture are still not considered as the pedagogical research issue.

Therefore, the significance and urgency of the research topic are defined by the significant potential of public associations in the development of civil culture from one side, and its partial implementation, due to its limited interpretation of the socio-cultural and pedagogical essence of this phenomenon from the other, as well as the theoretically undeveloped conditions for encouraging civic participation.

\section{Problem Statement}

This purpose resulted in a need to address a number of problems in a coherent manner:

1. Characterize the main theoretical approaches to the definition of civil culture as a social and pedagogical phenomenon.

2. Regard the functions of public associations as a structural element of civil society and the conditions for the individual self-realization.

3. Characterize the forms, problematic areas and spheres of public associations' activity.

4. Specify the best methods and forms of social partnership of public associations in the process of resolving socially significant problems

5. Identify the development resources for the civic activity of the "third sector" subjects.

6. Identify the social and organizational and pedagogical conditions for the development of participants' civil culture in the public associations.

\section{Research Questions}

The preliminary study of the problem allowed the formulation of the research hypothesis, which consisted of the following assumptions:

1. The civic culture education of public association's participants is effective, if a result of purposeful efforts is the development of the social and organizational-pedagogical conditions that encourage the civic activity.

2. The greatest potential in the civic culture development is played by the public associations included in the system of social relations (with the power structures, business, the "third sector" actors) on implementation of the socially significant projects.

3. The most important external condition for activating a civic participation is the creation of such public associations' integration into regional socio-cultural policies models, able to demand technologies and forms of participation, adequate to the nature of the "third sector" in solving socially important problems. 


\section{Purpose of the Study}

The set of problems identified above determines the relevance of the research, which goal is to study public associations as a structural element of civil society and to determine the social and psychological-pedagogical conditions for the development of the civil culture of their participants.

\section{Research Methods}

The theoretical basis of the research is the works of Russian and foreign philosophers, sociologists, teachers that grounded the socio-pedagogical essence of public associations, revealed various aspects and facets of the civil culture as a phenomenon. The problems of civic participation are reflected in the sociology of social movements, the theoretical basis and subject of research are the concepts of collective action, social networks, resource mobilization and social deprivation (M. Diani, A. Jemison, J. Cohen, J. McCarthy, N. Smelser, A. Turen). The theoretical foundations of civil society are covered in the works of A. Arato, V. Barber, E. Gellner, A. Gramsci, J. Cohen, T. Parsons, M. Ritter, A. Seligman, K. Taylor, J. Habermas. Various approaches and models of civil society in the modern Russian context are contained in the studies of A. S. Avtonomov, A. A. Galkin, E. V Belokurova, N. Yu. Belyaeva, G. G. Diligensky, T. Zaslavskaya, Yu. A. Krasin, Yu. M. Reznik, A. Yu. Sungurova. The study of public associations as a form of civic participation is covered in the research of L. Agordon, A. B. Zdravomyslova, E. V. Kpopova, V. V. Kostyushev, V. N. Yakimets, O. Yanitsky.

Theoretical and methodological basis of the work was: the concept of civil society, under which the socially responsible participation of citizens in solving the actual problems is considered as a system-forming principle of civil society and the criterion of the individual's developed civil culture; an activity approach that allows to consider the phenomenon of civil culture at two levels: as a result of the objective and external factors of the "social environment" and as an internally motivated activity of the individual, aimed at optimizing relations and contradictions in the "society-individual" system, creating conditions that harmonize the human social being; a methodological apparatus for studying public associations and movements, formed within the framework of the theory of sociocultural activity (M. A. Ariarsky, T. G. Kiseleva, V. E. Triodin).

The theoretical basis for the study of public associations as a socio-cultural phenomenon is the works of well-known philosophers and culturologists, namelly S. N. Ikonnikova, A. Zapesotsky, B. D. Parygin, E. V. Sokolov. In the development of psychological and pedagogical aspects of the topic, the author relied on the works of G. M. Birzhenyuk, L. G. Bryleva, A. Markov, B. A. Titov, A. Sukalo.

\section{Findings}

1. The concept of public associations as a structural element of civil society and the space for the development of participants' civil culture whose activity is determined by the social responsibility and the desire to fully meet the needs of social contacts, recognition, self-respect and self-realization.

2. Socio-cultural conditions for realizing the potential of public associations as mean of developing a civic culture of participants, including: strengthening the social significance of the associations' activities and raising the social status of the "third sector" (defined by the corporate mission of the organization, its values, vision of urgent social problems and real participation in their decision, favourable public opinion in relation to the activities of 
public associations); stimulating civic engagement of participants (by increasing their motivation of participation in the projects that solve socially significant problems; affirmation in the public consciousness of participation in the activities of public associations as an effective means of personal development and an essential component of the civil society life; development of mechanisms and forms of functional and structural integration of public associations into the regional socio-cultural policy (by consolidating the right of public associations to participate in targeted social programs, advisory and expert councils, including expert and analytical activities to develop normative acts and review programs); integration and conversion of the resources of public associations by development of regional and national associations and consultative and coordination structures capable of coordinating the activities of various non-profit organizations, creating mechanisms for self-control and self-regulation, expanding the forms of communication and partnership; organization of information and educational and methodological activities of "infrastructure" associations for the development of the "third sector" through the organization of a permanent system of training managers for non-governmental non-profit organizations-specialists able to drive the social policy, who knows PR technologies, fundraising, methods and forms of organizing social partnership; approval of the principles of social partnership and intersectoral interaction by promoting among the public associations the ideology of cooperation and the effectiveness of consolidation by building mutually beneficial relations between public associations, business and public authorities.

3. Socio-psychological (inside groups) conditions for activating civic participation, suggesting: optimization of the organizational structure (by distributing functional-job duties in accordance with the personal potentials and characteristics of the participants, organizing teams that are optimal in terms of psychological characteristics, delegating responsibility to employees); formation and update of the "portfolio" of orders that are socially significant; including the maximum number of association participants in the setting up of the mission, strategy and direction of the association, the development of projects implemented in the social partnership regime; raising the level of the project culture of directors and leaders of public associations.

4. Psychological and pedagogical recommendations aimed at preventing and minimizing interpersonal conflicts among members of public associations by: adjusting the ideology of public association, expanding or changing the scope of activities, enhancing the social and personal significance of the participants' civil initiatives, creating additional conditions for individual development, creating a positive psychological climate, improving the organizational structure of the association.

5. The social partnership model of public associations with business and government structures in the solving significant problems, based on:

a) The principles of mutual responsibility, constructive, focused and mutually beneficial cooperation, guaranteed by the consideration of motives and the correspondence of mutual partners' expectations;

b) An agreed normative and legal framework (understood as a set of normative documents - the basis for legitimate forms of cooperation, for regulation of the project participants' behavior, for specification of norms for sharing resources);

c) The development of organizational structures and mechanisms that allow to cooperate and convert the financial, economic, administrative, personnel, information, technological and other resources of partners.

\section{Conclusion}


The process of building the civil sector has significantly accelerated in recent years. It became an instrument of social policy, a school of political culture, and a form of civic participation. In their activities, they rely on modern concepts of civil society that have developed in the liberal culture. Directly or indirectly, their ideological platforms include the values of a free individual, the principles of the rule of law and private property, the security of all actors against arbitrary decisions, free press, as well as compliance of domestic legislation with universally recognized norms and principles of international law.

Socio-cultural and political changes in the country have caused a rapid growth of public associations, the strengthening of their civic position. Beginning with the emergence of the idea and the creation of a team, the establishment of an organizational structure, through the acquisition of planning, design and fundraising skills, increasing the level of staff competence, fighting for the organization reputation, looking for open segment in the social services market, public associations achieve the status of a strong partner with various authorities and businesspersons, because they are able to defend the interests of citizens and society.

Realization of the public associations' potential as a means of forming a civic culture depends on the ability of the "third sector" to attract additional development resources. They, in turn, are related to the quality of partnerships. The development of a mutually acceptable strategy for intersectoral development in Russia is possible if the boundaries of the state and civil society functioning are defined, the areas of their separate responsibility and joint activities are determined and the role and place of public associations in the development processes is shown.

One of the most effective forms of civic culture education are club associations whose pedagogical and creative abilities have been tested by historical experience. The natural desire of people to unite on the basis of spiritual, cultural, material and other needs and interests is proved by the historical experience of the life activity of people all over the world. Today, many amateur associations raise to the level of organized social action, and on this basis a socially active person, who is able to fulfill the new tasks, is formed. The activity of amateur associations and clubs on interests can be more effectively developed on the basis of interaction of various social institutions and departments. Significant importance in this case has the revival and preservation of traditional folk culture, the national cultural heritage, which is the foundation of spiritual improvement of the society and plays a huge role in the formation of spiritual and moral ideals and the best national traits, enhancing the people national self-awareness. In club associations, favorable pedagogical conditions are created for self-education, self-activity, self-expression, selfaffirmation, creative self-realization, self-management, and self-knowledge; here a sense of collectivism, mutual support, mutual assistance, comradeship and friendship is formed, cultural and everyday traditions, relevant and specific for a given social environment, are affirmed. Modern business sector transformation and the formation of the "third sector" can help to focus efforts on reducing the scope of tasks facing state bodies, transferring a number of their functions to the market and civil society. It is necessary to support the worldwide regional cultural initiatives, assist local governments that are a basic link in the implementation of federal and regional programs. Such power redistribution is in favor of local government, the market and the public sector should be accompanied by the actions of the authorities to create legal, economic and organizational conditions for the development of the civil sector. It is advisable to narrow the scope of direct administrative influence on the civil life of society, which implies the presence of diverse areas and forms of the society itself; the possibility of public control and openness of the power structures' activity should be guaranteed.

The conceptual basis, principles, strategic goals and priorities of the regional policy in relation to the "third sector" should be built on the basis of an optimal combination of 
regulation and self-organization, direct and reverse linkages, on the personal dimension of all the transformations being implemented, the optimal balance of social, economic and spiritual factors of human existence. As part of the efforts of state structures, it is necessary to create conditions that minimize the destructive activity of informal groups and simultaneously stimulate socially approved forms of behavior and activities that promote maximum self-realization of the individual. These conditions should ensure the continuity of spiritual and moral traditions, the realization of the creative potential of the individual, the demand for its intellectual capabilities, by creating "growth zones" in various areas of material and spiritual production that conserve and expand the layer of the national spiritual elite. As the leading principles of such policy should be considered: the optimal combination of regulation and self-organization, direct and feedback in the process of developing and implementing the priorities; the prospects of the decisions made, their focus on the priorities of the future; democracy, provided by a combination of real rights and conditions for the citizen's participation as a full-fledged subject of social, economic, political and cultural life of the society.

Considering the processes taking place in the society, the state policy should be aimed at stimulating the active lead of the clubs to the social sphere. Associations should contribute to solving social problems in the region by offering models of an active, healthy, socially useful way of life. They are directly obliged to participate in the "treatment" of social diseases such as drug addiction, alcoholism, crime, prostitution, etc. This participation can be expressed in the form of determined proposals alternative to socially ugly forms of leisure, life-giving, socially significant recreational programs. Cultural and leisure institutions, choosing the forms of organization of leisure, should proceed from the fact that any action should rise the social activity of participants, moral principles, kindness, humanism, clemency, charity - universal values, laid in everyone regardless of their nationality.

Within the cultural policy framework, it is necessary to create conditions conducive to the development of all forms of social activity, and, first of all, club forms of independent activity as the most optimal for the personal development and the formation of non-conflict forms of civic engagement. It is required to create a favorable regulatory and legal and social space for the realization of the educational potential of amateurism - by educating leaders of associations with promising technologies, creating a unified information system for club activities in the region and a bank of innovations in the cultural and leisure sphere, taking into account nationality, age, territorial and other characteristics of the population. The main emphasis should be made on creating the conditions for the club activity selfdevelopment, the consolidation of involuntary social and cultural ties. The basis of such a process can be any activity that unites the people interested in it and has a personal and socially significant character.

Civil society in Russia is in its nascent stage. And in this process, a special role belongs to public associations in which the personality passes the school of civic participation. And this trend is objectively natural. The specificity of the modern world is the development of global dangers. This can be resisted by a single force - a person building up his spiritual potential. His answer to the challenge of the time should be the focus on the formation of his creative potential, on the formation and realization of his moral and civic duty.

Prospects for the development of public associations as the most important direction of the civil culture education are associated with a deep and comprehensive understanding of the role of this social institution in the life of the society. The meaning of human existence, the idea of a person's place in this world is changing, the understanding of personality as the highest value come to the fore. But changing himself, a person changes the society. This is the main social and moral mission. 


\section{References}

1. E. O. Belikova, A. G. Nesterova, Obshhestvennye obedineniya kak sredstvo formirovaniya grazhdanskoj kultury $v$ regione (na primere Volgogradskoj oblasti) (VSU, Volgorgad, 2010)

2. G. M. Birzhenyuk, A. P. Markov, Osnovy sociokulturnogo proektirovaniia: uchebnoe posobie (Spbgup, St. Petersburg 1998)

3. N. V. Volkova, L. A. Guseva, Modern Problems of Science and Education, 5 (2013)

4. G. Kh. Kalimullina, D. D. Kalimullin, Obshhestvennye obedineniya kak faktor formirovaniya grazhdanskoj kultury molodezhi (Brig, Kazan, 2016)

5. N. Yu. Kiryushina, Pravovoe regulirovanie obshhestvennykh obedinenij: uchebnoe posobie (N. Novgorod, 2012)

6. A. P. Markov, Proektirovanie marketingovykh kommunikatsij: uchebnoe posobie (SPbGUP, SPb, 2005)

7. D. I. Pletnev, Civic culture as a culture of the consent of society and the state (Tomsk, 2005)

8. R. G. Salakhutdinov, Socio-cultural creativity (B.I., Kazan, 1997)

9. L. A. Sankin, Socio-cultural activity: theory and methods of organizing the activities of public associations (SPbGUP, St. Petersburg, 2006)

10. P. Sorokin, Human. Civilization. Society (Politizdat, Moscow, 1992)

11. V. Ya. Surtaev, Molodezh i iskusstvo (SPbGUKI, St. Petersburg, 2002)

12. The Tatars and Tatarstan (Kazan, 1993)

13. M. S. Glukhov, Tatarica: Encyclopedia (Vatan, Kazan, 1997)

14. R. R. Timerbaev, A. A. Kadymov, Obshhestvennye obedineniya kak strukturnye ehlementy grazhdanskogo obshhestva (Moscow, 2011)

15. A. Tokvil, O demokratii v Amerike (Progress, 1987)

16. V. V. Tuev, Tekhnologiya organizatsii initsiativnogo kluba: Ucheb. posobie dlya vuzov iskusstv i kultury (MGUKI, Moscow, 1999)

17. V. E. Triodin, Klub i svobodnogo vremya (Profizdat, 1982)

18. S. A. Chulyukaeva, Obshhestvennye organizatsii (obedineniya) $i$ ikh rol v stanovlenii grazhdanskogo obshhestva (Akademia Estestvoznaniya, Moscow, 2012)

19. P. I. Yakovlev, Bulletin of the Tambov University - Series in the Humanities, 12, 104 (2011) 